\title{
The Russian Hotel Market: Condition and Development Under the Crisis
}

\section{Elena A. Dzhandzhugazova}

Plekhanov Russian University of Economics, Russian Federation

Nataliya A. Zaitseva

Immanuel Kant Baltic Federal University, Russian Federation

Anna A. Larionova

Moscow State University of Design and Technology, Russian Federation

Sergey N. Pervunin

Moscow State Engineering University (MAMI), Russian Federation

Email: annla@list.ru

Doi:10.5901/mjss.2015.v6n3s5p289

\begin{abstract}
The aim of the present research is to study the condition and development of the Russian hotel market under the crisis. The authors have analyzed the existing threats, defined the main trends of development and systemized all significant results of the research. In the course of the present work the methods of systematic approach, economic and statistic analyses, quantitative and qualitative studies have been applied. Such methods allow to reveal the problems and prospects of the Russian hotel market development. The article presents the results of analyzing the state of the Russian hotel market: the investment activity, the dynamics of the operational indicators of the Moscow, Saint Petersburg and other regions hotels' activity. The paper also provides the authors' appraisal of the degree of external factors impact on the Russian hotel business development. The special focus is placed on scrutinizing the issue of the human factor in the hotel business. Present analysis shows that different segments of the hotel market respond to crisis in different ways, it allows revealing the main threats for the Russian hotel market as well. The authors of the research have emphasized the necessity of the holding of the anti-crisis measures, aimed at the adjustment of the approaches to the hotel business management under the condition of the fluctuating market. The top priority steps are: the improvement of the marketing policy and the restructuring of the business processes. At the resume-part of the research the authors have concluded that despite the complex situation international hotel operators still are not planning their outflow from the Russian market, that attests to its long-term attraction. Furthermore, as a result of the present research the necessity of the reform of the hotel-business staff training system has been proved. All authors' references aim at the overcoming the negative tendencies on the Russian hotel market, caused by current crisis.
\end{abstract}

Keywords: hotel market, service sector, economic crisis, hotels

\section{Introduction}

Over the last few decades, the hotel market has become crucial in the system of the industry markets of the service sector. Mass tourism development, increase in business activity and communication have contributed to the creation of the modern industry of hospitality, oriented at different customer ranges. Russian economy experience of development during the period of 1998-2000s and global economic crisis of 2008 indicates that hotel market as almost any market actively reacts to crisis, what is more, this reaction can be both negative and positive simultaneously.

Impact of the crisis on the enterprises in terms of strategic, labor, innovative aspects, as well as the life cycle is presented by the works of the leading Russian and foreign experts, among which (Keynes, 1997; Drucker, 1999; Kotler, 1994; Porter, 1998; Ansoff, 1988; Mau, 2009; Lvov, 2002; Glazyev, 2009). However, a lot of theoretical and practical issues related to the study of the crisis factors and anti-crisis measures in the hotel business industry remain insufficiently explored. It is commonly known that an economic crisis cannot be avoided completely, but along with the studying crisis impact on the market preventive measures should be taken and consequences reduced. 


\section{Literature Review}

The state and development of the hotel market under the crisis has been investigated by Russian and foreign researches, anti-crisis measures have been taken as well.

As a result of the study of the reaction of the Spanish hotel sector to the financial crisis of 2008 (Alonso-Almeida \& Bremser, 2013) it was found out that its impact on the hotel business had been stronger than in other industries. This paper offers an increase of expenditures for the hotel marketing and points that cost-cutting measures lead to the decline in demand. The articles (Campo \& Yagüe, 2014; Ivanov \& Mayorova, 2014) also highlight the positive impact of the marketing tools usage on the hotel business efficiency. The study of the process and marketing innovations (Nicolau \& Santa-María, 2013) and novelty in tourism (Thomas \& Wood, 2014) has revealed that they have the greatest positive impact on the hotel market. The article (Chen, 2011) presents the results of the research of the Taiwan hotels reaction on crisis in 1999, 2001 and 2003 years. The author concludes that the development of the international tourism has the greatest impact on hotel sales and profitability. The problems of the sustainable tourism development in the European market are reviewed in the article (Olli, 2013).

Assessment of the impact of 2008 financial crisis on the Russian hotel market is presented in the works of Zaitseva (2013) and Pecheritsa (2012). The basic models, mechanisms and instruments of anti-crisis management in the hotel business are offered in works of Ivanov and Volov (2010) and Dzhandzhugazova (2013).

The paper (Ivanov \& Volov 2010; Dzhandzhugazova, 2014) notes that one of the main factors of the realization of the anti-crisis management in hotel business is staffing that requires the availability of properly-trained managers. The problems of formation of the staff managing system which is able to provide the formation of high personnel potential and involve staff in the innovative process are reviewed in (Nonano et al. 2005; Ghorbani et al., 2013; Dmitrieva et al., 2015).

The results of taking researches are the following: firstly, the reaction of the hotel business to crisis is different from region to region; secondly, the sources of the crisis phenomena stipulates a set of special anti-crisis measures; thirdly, up-to-date there are no systematic studies of the 2014 crisis impact on the Russian hotel market.

\section{Methods}

The key elements of the analysis are: demand, supply, level of competition, estimates, customer and other market practitioners' behavior. The aim of the analysis is to reveal the current state of the market and its perspectives, the main trends and problems, taking into account the crisis.

As a material for the article the authors used such sources of information as RF Rosstat materials, the real estate market surveys, analytical reports data (EY Company, 2015; JLL, 2015; Inflyatsiya v Rossii, 2015; SuperJob.ru, 2015), information, obtained as a result of independent research of the hotel market enterprises by means of observing and interviewing, as well as information contained in scientific and periodical literature.

In the course of research, the desk methods of investigation have been widely used. They allow assessing the potential and development opportunities of the Russian hotel market as well as to carry situation analysis of the main market players' behavior.

Methodological basis of the research has been formed both on traditional methods of quantitative and qualitative measurements, such as observation, comparative analysis, the method of expert evaluations and on special marketing methods, in particular, Conjoint analysis (CA). This method, based on logic of the joint analysis, allows determining the best configuration of anti-crisis hotel offer on the basis of existing and new hotel products and services, by comparing the key attributes of supply. The results of the research will enable to answer the key question-who is the winner and who is the looser among the hotel market players?

The question is raised, as the right steps concerning the management of the income of the different-price segment hotel enterprises are to be determined. The analysis of the previous crisis consequences shows that different segments of the hotel market respond to crisis in different ways, it means that demand has an equal reaction. Some hotel services keep demand on the stable or even increasing level. This fact proves the necessity of diversified and multivariate approach to the hotel market research.

\section{Results}

\subsection{Hotel market: general condition}

Today, domestic hotel market is represented by more than 13 thousand of hotel enterprises. Its capacity is estimated at 
300 billion rubbles. A larger share of the market (70\%) is occupied by Moscow and Saint Petersburg, but regions' share is constantly growing.

The Russian tourist flow structure was reflected by the complex international situation. The amount of the Western Europe tourists reduced, but the amount of the Asian tourists did the opposite. But, as the tourists from Asia spend on accommodation services a third less than European and American ones, they still do not cover the decrease in revenue caused by the above-mentioned reduction.

Detailed study of the hotel market key trends shows that the room stock in 2014 increased basically at the expense of luxury segment hotels, though demand concentrated on the hotels of Midscale and Upper-midscale segments. Prominent international hotel operators are active as usual. Thus, during the years 2013-2014 37 new hotels were opened. With that, investment activity in the capital market differs from that of the regional.

In 2014 in Moscow Four Seasons Hotel (capacity of 180 rooms) opened its doors, 2 hotels-Mercure Moscow Baumanskaya (47 rooms), by Accor Group and Intourist Kolomenskoe (259 rooms), by Intourist Hotel Group were put into operation. Moreover, the offers concerning the construction of brand-new hotels near airports increased in number.

In 2014 4-stars Hotel Indigo St. Petersburg (119 rooms) was opened in St. Petersburg, also Park Inn by Radisson Pulkovo Airport, running by Carlson Rezidor Hotel was put into operation.

International operators found a record number of hotels in the regional hotel markets over the first quarter of 2014: 8 objects with capacity of more than 1500 hotel rooms, among them four hotels (each with capacity of 900 hotel rooms) were put on line in preparation for the Olympic Games in Sochi. The hotels of Upper-midscale segment turned to be in a better position. International hotel chains remain active regarding the new projects. Thus, the projects of such hotels as Courtyard by Mariott in Nizhny Novgorod (150 rooms, opening in 2015), Holiday Inn in St. Petersburg (180 rooms, opening in 2015-2016) and Hilton Garden Inn in Bryansk (160 rooms, opening in 2017) were claimed.

The current situation reflected on the development of the new projects, as a result, scheduled opening of four hotels with capacity of 2000 hotel rooms was transferred to the year 2015. At once, all hotels under construction are planned to be put into operation, but new projects at an initial stage are to be conserved.

In spite of the complex situation international hotel operators still are not planning their outflow from the Russian market. It attests to its long-term attraction.

Russian brands are not actively promoted in the market, but hotel marketing has significant prospects, as more than $60 \%$ of Russian hotels operate under little-known brands. Of course, crisis continues to sour, and the hotel market is anticipating the hard times. Exactly this stresses the importance of systematic marketing research, the result of which will allow creating a program of development under crisis.

At the end of 2014, EY Company carried out studies devoted to the tendencies of the Russian hotel business development in the current economic climate. The participants were $65 \%$ of developers and $35 \%$ of hotel operators. Survey response identified that $63 \%$ of hotel operators had not changed their business strategy under the complex geopolitical situation and sanction pressure on the Russian economy, and only $37 \%$ of operators had conserved their development plans. The current situation and hotel development are estimated as rather stable. Thus, $33 \%$ of developers assess their business as profitable and $54 \%$ as stable. More than $60 \%$ of respondent operators and developers are planning to optimize their expenses and run business more efficiently.

It should be mentioned, that the 2014-year-forecast predicts decrease in tourists' flow, and in income of Russian citizens. But the conditions in the hotel market are less alarming in comparison with other markets, especially with the catering market, where demand is to be reduced almost twice.

\subsection{Operating results of the hotels' activity}

Analyzing the negative tendencies' impact, it is important to realize that different segments of the hotel market respond to crisis in different ways. In particular, the hotels of the Luxury segment turned to be in more complex situation than those of the Midscale segment.

As mentioned above, a larger share of the Russian hotel market is occupied by Moscow and St. Petersburg, thereafter, exactly this share is influenced by crisis in a higher degree than others. Let's analyze the changes in the operating results of the hotel activity in Moscow and St. Petersburg. The data is presented in Table 1 and Table 2. 
Table 1. Dynamics of Average daily rate (ADR, P), Revenue Per Available Room (RevPAR, $P$ ) and Occupancy Rate (Occ, \%) in Moscow for 2013-2014 years

\begin{tabular}{|c|c|c|c|c|c|c|c|c|c|}
\hline \multirow{3}{*}{ Hotel segments } & \multicolumn{3}{|c|}{ ADR, $P$} & \multicolumn{3}{|c|}{ RevPAR, $P$} & \multicolumn{2}{|c|}{ Occ, $\%$} & \multirow{3}{*}{ Rec. } \\
\hline & 2013 & 2014 & Rate of growth, & 2013 & 2014 & Rate of growth, & 2013 & 2014 & \\
\hline & year & year & $\%$ & year & year & $\%$ & year & year & \\
\hline Luxury & 13000 & 12610 & 97 & 8464 & 7910 & 93.5 & 66 & 61.8 & -4.2 \\
\hline UpperUpscale & 9800 & 10000 & 102 & 6400 & 5951 & 93 & 68 & 59 & -9 \\
\hline Upscale & 6100 & 6000 & 98.4 & 4650 & 4000 & 86 & 73 & 65 & -8 \\
\hline UpperMidscale & 5900 & 5580 & 94.6 & 4050 & 3850 & 95.1 & 70 & 71 & 1 \\
\hline Midscale & 4500 & 4200 & 93.3 & 3260 & 3000 & 92.0 & 70 & 69 & -1 \\
\hline
\end{tabular}

The results of the research point to reduction in the operating results of the hotels activity in 2014 in comparison with 2013.

Hotels of Luxury segment do not demonstrate the features of drastic fall in operating results, although, it is a first time after the financial crisis of 2008-2009, when RevPAR and Occ indicators show negative index. Four Seasons Hotel is not taken into account, as its impact on the market is to be rated only in 2015. Luxury segment clients' income stays at the pre-crisis level. Therefore, the conclusion is that demand on luxury hotel services is constant and not influenced even by crisis.

Upscale and UpperUpscale segments have faced a significant decrease in demand. This situation is due to the characteristics of the hotels of this segment: most of the objects have a high capacity. Among the Moscow hotel market this segment is the most competitive. In our opinion, this competition is rising: among number of projects Mariott (234 rooms) plans to open a hotel on Novy Arbat. In 2015 UpperUpscale segment is waiting for the decrease in ADR index.

The fall of Occ index is caused by the decline in business demand and business trips. Middle class, whose income is influenced most by the crisis represents the main part of the hotel residents. UpperUpscale hotels depend on tourist's groups. It will be difficult for the hotels of present segment to regain their operating results in 2015.

It should be mentioned, that only Midscale segment presents stable Occ index, as these hotels have stable demand on their accommodation.

Russian tourists represent the largest part of the hotel residents. Midscale hotels have a less room stock, that in combination with central location, good quality brand and full range of services contribute to crisis-resistance of this segment. Let us analyze the situation in the St. Petersburg hotel market.

Table 2. Dynamics of Average daily rate (ADR, P), Revenue Per Available Room (RevPAR, P) and Occupancy Rate (Occ, \%) in St. Petersburg for 2013-2014 years

\begin{tabular}{|c|c|c|c|c|c|c|c|c|c|}
\hline \multirow{3}{*}{ Hotel segments } & \multicolumn{3}{|c|}{ ADR, $P$} & \multicolumn{3}{|c|}{ RevPAR, P } & \multicolumn{2}{|c|}{ Occ, \% } & \multirow{3}{*}{ Rec. } \\
\hline & 2013 & 2014 & Rate of growth, & 2013 & 2014 & Rate of growth, & 2013 & 2014 & \\
\hline & year & year & $\%$ & year & year & $\%$ & year & year & \\
\hline Luxury & 11000 & 10000 & 90.9 & 5500 & 4600 & 83 & 55 & 48 & -7 \\
\hline UpperUpscale & 7800 & 7000 & 89.7 & 4400 & 4100 & 93.2 & 60 & 55 & -5 \\
\hline Upscale & 5000 & 4700 & 94.0 & 3000 & 2850 & 95.0 & 60 & 60 & 0 \\
\hline UpperMidscale & 3900 & 3780 & 96.9 & 2740 & 2550 & 93.1 & 68 & 64 & -4 \\
\hline Midscale & 2800 & 2843 & 101.5 & 1950 & 1830 & 93.8 & 69 & 62 & -7 \\
\hline
\end{tabular}

The rising competition has a negative impact on the operating results of the Luxury hotels. Four Seasons Hotel was run into operation under the condition of a strong competition. Summit G20 taking part in September 2013 served as a ground for fluctuations of hotels' activity operating results. This event caused a rapid growth of tariffs in all market segments, thus, RevPAR index for September 2013 was 74\% higher compared to September 2012.

UpperUpscale hotels have the same tendencies as Luxury, but the pace of the index change is slower. For instance, Occ index of the UpperUpscale segment in London and Paris exceeds 80\%, in Budapest, Vienne, Prague, Venice makes up more than $70 \%$. Upscale hotels try to keep the occupancy rate at the stable level. Occ index remains at the level of 2013 due to the growth of internal tourism. It is worth mentioning that operating results of the Upscale hotels activity are more effective than those of the hotels of upper segments (in comparison with 2013). Midscale hotels have the best operating results. Only this segment shows a positive dynamics of ADR in rubles.

Thereby, crisis has made a negative impact on the St. Petersburg hotel market. However, some positive aspects 
should be noted. Though 2014 tourist season was uneasy, yet it brought a leadership to St. Petersburg as the main sightseeing direction in Russia. The level of incoming tourism has reduced; the number of Chinese tourists has increased by $10-15 \%$ in contrast to the tourists from the USA. The volume of internal tourism has raised by $40-45 \%$ during the period of the ruble's decline; most Russians have preferred vocations in Russia than abroad.

The situation in the regional hotel markets is ambiguous. For Sochi, for instance, hosting of such event as Winter Olympic Games was the turning point in the developing of the hotel business in this region. All the room stock of the mountain cluster had been booked to the October 2014. The New Year vocations of 2015 brought $90 \%$ occupancy rate to the Sochi hotels, but the Occ index from January to August did not exceed 25\%. Another Russian city, hosting a largescale event in 2013, is Kazan. Kazan hotel market faced a rapid growth in 2013. But Occupancy rate in 2014 was 47\% altogether that is $13 \%$ lower than in 2013. It is the consequence of the oversupply. Hotel holders and managers are forced to operate flexibly with the tariff rates to keep Occ index on the stable level. Unfortunately, the object of their competition is price, not service quality.

Novosibirsk is one of the tourist's centers in the Asian part of Russia. Novosibirsk is the third largest city in Russia (after Moscow and St. Petersburg), but the number of hotels in this city is only on the sixth place. Midscale hotels amount is twice less than, for instance, in Yekaterinburg. The Midscale Occ index is about 55-60\%. Domestic business tourists form the basic demand (85\%). Novosibirsk hotels still do not review their pricing policy despite the demand reduction-the rates for accommodation remain at the previous-year level. But, taking into account the opening of the Domina Hotel (207 rooms), Park Inn Hotel (150 rooms), Ibis Hotel (208 rooms), the hotel market can face a strong tariff competition in 2015.

All famous hotel chains in Russia have already encountered with the cutback of the hotel revenues. Thus, the Rezidor Hotels Group in its third quarter reporting fixed a 15,2\% decrease in RevPAR index in Russia (it is twice more than in the second quarter-7,7\%). All the rest European countries, except Ukraine, had a positive RevPAR index. The worsening of the financial positions is linked with the complex political situation in Russia. Accor-brand hotels had a 5\% decrease in RevPAR index for the last 9 months of the 2014. The senior management of the company points that a larger share of the hotels operates in Midscale segment that is a priori a less vulnerable direction. Cutback in revenues and occupancy rate is actual mostly for Moscow and St. Petersburg, the situation in regions almost has not changed (Gerashchenko \& Mertsalova 2015).

Thus, the analysis of the hotels' activity in regions showed that the Luxury segment is the most vulnerable and dependent on demand.

\subsection{Labor recourses}

The Russian hotel market even under the condition of crisis continues to develop in the direction of good-quality supply, though the current situation affects. A significant part of the problems of the hotel business is related to the labor resources. In spite of the increasing role of the service sector in the world economy, the prestige of work in this area is still not high, according to many researchers. It reflects the students' choice of forms of education, professions and directions of training. Most people nowadays choose high education, when there is a lack of labor resources in this area. Besides the unpopularity of the work in present sphere, the level of the salary in the regions is lower than the average level. So the question is: how to hold available hotel staff in the conditions of the limited benefits.

All these factors made a negative impact on the professionals and beginners' loyalty towards their employers. The consequence is a fast turnover of the staff in the hotel sphere, especially among room stock and catering services. So, the additional expenses are spent on the selection and training of the personnel. Yet it does not guarantee the providing of the good-quality services.

\section{Discussion}

As a result of taking research it was found out that current situation should not be considered as a negative, as over the last 10-15 years the hotel market has been stable, but the future threats should be taken into account. In current situation, we have identified a number of negative tendencies and offered anti-crisis measures:

Nonuniform fall in demand on the hotel services in different price segments-maximum in Luxury and minimum in Midscale. As a priority task for the overcoming of the negative consequences of the accommodation demand diversity in different price-segments can be a policy, directed at the activation of demand on Midscale services due to the attraction of Russian tourists from the regions. Certainly, these measures will require some rearrangement of the common direction of the hotel management and marketing. Though, the losses in income owing to the Luxury segment guests' outflow cannot be made up completely, in general, market activity will be saved. In our view, regional hotel markets need support 
on the federal and regional levels. For example, in November 2014 it was the first time then the Tourism Development Committee of St. Petersburg held professional working meetings and presentations of the tourist programs and hospitality services in St. Petersburg within the road show «Welcome to St. Petersburg». The development of youth and children's programs was given a special attention. It is innovative for St. Petersburg format of the event. From the one hand, it aims to the support of hotel business and tour operators, from the other hand, on the city promotion and attraction of new tourists.

Decrease in revenues as a result of the decrease in Average daily rate. In this case, by way of primary measures hotels may develop a wide range of the additional paid services, the sales of which will allow regulating hotels' revenues. Such offer can be based on the implementation of the sightseeing service for the residents that can be organized with the attraction of excursion offices, tourist's info centers and other partners of the tourist's market.

Decrease in the investment activity in the hotel market. The creation of the hotel infrastructure is financed mainly at the expenses of the borrowed funds. Their share in the total costs of objects is not less than $70 \%$. Taking into account the fall in the investment activity, the problems of finance will become more critical, that can impact the tempo of the running of the new objects. Of course, the negative consequences of the outflow of the investors cannot be neutralized significantly, but they can be softened mainly due to the change of priorities. The matter is that even under crisis welldeveloped markets continue to grow, but this growth is irregular and depends on the segment. Therefore, it is necessary to distinguish new priorities, such as support of programs in the growing segments and delay in sectors with a slow growth.

Ruble rate decline and increasing inflation. The main factor, which determines the development of the negative tendencies in the beginning of 2014, was the reduction in foreign tourists' flow due to complex geopolitical situation, rapid ruble rate decline and inflation. The level of the gross profit was badly influenced by the inflation, increase in prices on imported goods and sanctions. Thus, the main problem in the hotel market is linked with the growth in expenses and fall in value of objects. Hotel business is characterized by a high-capital coefficient not only at the construction level, but at operational either. So, taking into account the share of the imported materials and difficulties in serving debt in foreign currency (in condition of the ruble cash flow) anti-crisis measures include reviewing the investment programs and cost optimization.

Fall in EBIT, NOPAT in the hotel business as a result of the decline in the operational results. With the remaining instability of the foreign policy situation, as well as continuing ruble rate decline, it can be forecasted that the negative dynamics of EBIT and NOPAT index will continue in 2015.

Drop in prices under crisis should not be considered as the only way to gain an increasing market share-it can be a serious mistake. Even inconsiderable fall in hotel revenues can make a negative impact on EBIT of the whole business. In this regard it is necessary to reassess the ratio of costs and revenues. Almost every hotel under favorable environment has formed business-spheres with a low level of efficiency, where the cut in expenses is a justified step that will not lead to the negative after-effects. The effectiveness of the operational activity can be improved by means of restructurization:

- reduction in hotel participation in marketing events with low efficiency-for instance, in exhibitions with low return;

- increase in the share of own distribution channels, reduction in the share of the mediators and overall costs of distribution;

- growth in residence profitability;

- increase in degree of integration of all departments, that sell hotel services: reservation department, sales department and reception.

Destabilization of the Russian tourist's market in 2014. Shaky situation in the tourist's market caused by mass bankruptcy of tour operators needs cardinal revision of the partnership programs between hotels and travel agencies. Russian hotels have to turn to the east and cooperate with tour operators, who will attract tourists from China, India and other Asian countries aimed at partnership with Russia. To activate the partnership programs, hotels need to set new marketing policy and strategy adjusted for continued sanctions and fall in tourist's flows from Europe and the USA.

Shortage of the hotel staff. The result of the above mentioned threats (decline in demand for hotel services, decrease in investment activity in the hotel development and others), and deterioration of overall macroeconomic situation in the country is the turn of the labor market from the «employee market» to «employer market». In 2013 on the basis of recruiting portal, on the average, one vacancy in a hotel business accounted for one candidate's resume, then in 2014 the number of resumes per one vacancy already increased to 3,7. The data for the first months of 2015 has not been provided yet, but, this research observe the increase in the number of the resumes. However, the increase in the number of the job seekers has not solved the problem of the labor recourses. Just as a qualified staff lacked then, so it is 
in deficit now as well. The core of the problem is that in late 2014-early 2015 with the numeral increase in the number of candidates for available vacancies, the qualitative increase was not observed. It means that the potential employees may be experienced and, thus, possess professional, but not personal competence. The ability to smile sincerely and in time, to find a way out of the conflict, sociability, stress-resistance: all these qualities are still in a shortage. To solve these problems, the whole system of the staff training should be changed-from the short-term programs to the educational programs of the colleges and universities. Professional standards, developed by professional community should become a basis for this activity.

Negative impact of the financial position of the hotel enterprises on the staff recruitment. Deterioration in the financial position of the hotel enterprises has led to the fact that they are less likely to apply recruitment agencies for the recruitment of the staff, even on senior positions. But there are still some problems. Firstly, the ability of the hotel senior management to control the work of the outsourcing companies is reducing. Secondly, with 2015-year changes in the migration policy regulations, the number of outsourcing company's quality offers becomes to reduce. A lot of companies, as a result of these changes in the labor market, have returned to he creation of their own services and more attentive preparation and promotion of own staff. In the current economic situation this way is considered as the most rational and, as a result, efficient.

Low efficiency of management at all levels. A modern hotel chief (from the line to the top manager) is downloaded with routine, solving of the problems with infrastructure, answering the inspector's claims, etc. Recruiting the managing staff, the hotel owners point to such core competencies as: the ability to set ambitious goals and to achieve them, enthusiasm, activity and other qualities that are important for any leader. But the prose of life is that now always these merits prove to be in demand. In the network business management system is based on the strict compliance of the norms and standards of the network. As a result, proactive and energetic employees lose motivation, adapting to routine. It reflects on the quality of their work and efficiency of the decisions. For the changing of the situation it is necessary to implement the programs of staff rotation and to improve the system of incentives in the hotel industry. The transition to the managing position in another chain hotel always means «way out of comfort zone», so it makes for the development of leadership qualities and managerial competencies on the whole. It is not the variant for the independent hotels. In their case it is necessary to give attention to the system of incentives. Granting of authority to a manager, proved his loyalty to a hotel and overgrown his level and setting of more challenging and ambitious objectives also contribute to the increase in the quality and effectiveness of the management system in the hotel.

The necessity to change the system of staff training for hotel business. As was mentioned above, almost a half of the graduates of the professional colleges are not going to continue working in this field. In this way, a significant part of the state budget is spent on the training of the staff for other industries. By now, catering, hospitality and tourism industries have developed a system of the quality corporate staff training on these specialties in the frame of additional professional programs. Under such programs the staff training is carried out in a short time-from 2 weeks to 6 months, depending on the profession and company's particular qualities. Herewith, the training is paid by the candidates themselves (trainees, job seekers) or by the interested company. In prospect, hotel business staff training will be carried out in two directions. Labor staff will be trained directly at the enterprises or at the industrial training centers within shortterm programs. Specialists and managers will be trained under the applied Bachelor system (the main system of education in Russia). This system involves the combination of theoretical and practical training in the field of future work within the educational practice. Thus, the staff training will soon meet the needs of the hotel market.

\section{Conclusion}

The conclusion based on this research states that, despite the complex geopolitical and economic problems, the Russian hotel market is to be diagnosed as mature and stable. But its primary objects need systematic study and reasonable regulation.

Different segments of the hotel market respond to crisis in different ways. In particular, the hotels of the Luxury segment turned to be in more complex situation than those of the Midscale segment.

Conclusions and recommendations formulated in this study can be used in hospitality enterprises by means of implementation of anti-crisis measures and prevention of the negative crisis impact. One of the prospects for the further study of this topic is the comparative analysis of the features of crisis impact and realization of the anti-crisis management in the service sector. The result of such research will make a significant basis for the development of new directions of the research of the crisis impact on the enterprises development. 


\section{References}

Alonso-Almeida, M., \& Bremser, K. (2013). Strategic responses of the Spanish hospitality sector to the financial crisis. International Journal of Hospitality Management, 32, 141-148.

Ansoff, I. (1988). The New Corporate Strategy. New York: John Wiley \& Son.

Campo, S., Díaz, A.M., \& Yagüe, M.J. (2014). Market orientation in mid-range service, urban hotels: How to apply the MKTOR instrument. International Journal of Hospitality Management, 43, 76-86.

Chen, M. (2011). The response of hotel performance to international tourism development and crisis events. International Journal of Hospitality Management, 30(1), 200-212.

Dmitrieva, N.V., Zaitseva, N.A., Kulyamina, O.S., Larionova, A.A., \& Surova, S.A. (2015). Scientific and Theoretical Aspects of the Staff Recruitment Organization within the Concept of "Talent Management". Asian Social Science, 11(3), 358-365.

Drucker, P. (1999). Management Challenges for the 21st. century. New York: Harper Business.

Dzhandzhugazova, E.A. (2013). Particularities of Creation and Promotion of New Ideas in Social Network Space. World Applied Sciences Journal, 27, 79-84.

Dzhandzhugazova, E.A. (2014). Turistsko-rekreatsionnoe proektirovanie. Uchebnik. Moskva: Izdatel'skiy tsentr «Akademiya». [in Russian]

EY Company. [Online] Available: http://www.ey.com/RU/ru/Industries/Real-Estate (February 8, 2015)

Gerashchenko, E., \& Mertsalova, A. Oteli drognuli. Kommersant.ru. [Online] Available: http://www.advertology.ru/article126676.htm (February 6, 2015). [in Russian]

Ghorbani, M., Bahramzadeh, H., \& Sami, A. (2013) The Study of Relationship Between the Dimensions of Knowledge Management and Readiness for Organizational Change. Middle-East Journal of Scientific Research, 13 (5), 594-605.

Glazyev, S.U. (2009). Mirovoi ekonomicheskii krizis kak process smeni tehnologicheskih ukladov. Voprosi ekonomiki, 3, 26-38. [in Russian]

Inflyatsiya v Rossii (2015). [Online] Available: http://уровень-инфляции.pф.aspx (February 8, 2015). [in Russian]

Ivanov, G., \& Mayorova, E. (2014). Business reputation and trade efficiency. Economic Annals-XXI, 1(1-2), 54-57.

Ivanov, V.V., \& Volov A.B. (2010). Antikrizisnii menedjment v gostinichnom biznese. Moskva: Izdatelstvo. INFRA.M. [in Russian]

JLL. [Online] Available: http://www.jll.ru/russia/ru-ru (February 8, 2015). [in Russian]

Keynes, J. M. (1997). General Theory of Employment, Interest and Money. Prometheus Books.

Kotler, P. (1994). Marketing Management: Analysis, Planning, and Control. Hardcover.

Lvov, D.S. (2002) Ekonomika razvitiya. Moskva: Ekzamen.

Mau, V.A. (2009). Drama 2008 goda ot ekonomicheskogo chuda k ekonomicheskomu krizisu. Voprosi ekonomiki, 2, 4-22. [in Russian]

Nicolau, J.L., \& Santa-María, M. J. (2013). The effect of innovation on hotel market value. International Journal of Hospitality Management, 32, 71-79.

Nonano, B.J. (2005). Introduction to organizational culture. New York press.

Olli, D. (2013). The Challenges for the European Tourism Sustainable. Mediterranean Journal of Social Sciences, 4(9), 464-468.

Pecherica, E.V. (2012). Cenoobrazovanie v gostinichnom biznese v usloviyah krizisa. Ekonomicheskii analiz; teoriya i praktika, 19, $34-$ 44. [in Russian]

Porter, M.E. (1998). Competitive Strategy: Techniques for Analyzing Industries and Competitors. New York: The Free Press.

Sankt-Peterburg. Obzor rynka gostinichnoy nedvizhimosti za 1 kvartal 2014 goda. [Online] Available: http://spb.arendator.ru/articles/ 133496-sankt-peterburg_obzor_rynka_gostinichnoj_nedvizhimosti_za_1_kvartal_2014_goda (February 6, 2015). [in Russian]

SuperJob.ru. [Online] Available: http://www.superjob.ru-Issledovatel'skiy tsentr portala -SuperJob.ru (February 2, 2015)

Thomas, R., \& Wood, E. (2014). Innovation in tourism: Re-conceptualising and measuring the absorptive capacity of the hotel sector. Tourism Management, 45, 39-48.

Zaitseva, N.A. (2013). The Forecast of Development of the Hotel Business in Russia as a Promising Direction of Business Expansion of International Hotel Chains. Middle East Journal of Scientific Research, 14(3), 328-334. 